\title{
Quantifying black carbon from biomass burning by means of levoglucosan - a one-year time series at the Arctic observatory Zeppelin
}

\author{
K. E. Yttri ${ }^{1}$, C. Lund Myhre ${ }^{1}$, S. Eckhardt ${ }^{1}$, M. Fiebig ${ }^{1}$, C. Dye ${ }^{1}$, D. Hirdman ${ }^{1}$, J. Ström ${ }^{2}$, Z. Klimont ${ }^{3}$, and A. Stohl ${ }^{1}$ \\ ${ }^{1}$ NILU - Norwegian Institute for Air Research, P.O. Box 100, 2027 Kjeller, Norway \\ ${ }^{2}$ Department of Applied Environmental Science, Stockholm University, 10691 Stockholm, Sweden \\ ${ }^{3}$ International Institute for Applied Systems Analysis (IIASA), Schlossplatz 1, 2361 Laxenburg, Austria
}

Correspondence to: K. E. Yttri (key@nilu.no)

Received: 13 November 2013 - Published in Atmos. Chem. Phys. Discuss.: 9 December 2013

Revised: 30 March 2014 - Accepted: 19 May 2014 - Published: 27 June 2014

\begin{abstract}
Levoglucosan, a highly specific tracer of particulate matter from biomass burning, has been used to study the influence of residential wood burning, agricultural waste burning and Boreal forest fire emissions on the Arctic atmosphere black carbon (BC) concentration. A one-year time series from March 2008 to March 2009 of levoglucosan has been established at the Zeppelin observatory in the European Arctic. Elevated concentrations of levoglucosan in winter (mean: $1.02 \mathrm{ng} \mathrm{m}^{-3}$ ) compared to summer (mean: $0.13 \mathrm{ng} \mathrm{m}^{-3}$ ) were observed, resembling the seasonal variation seen for e.g. sulfate and $\mathrm{BC}$. The mean concentration in the winter period was $2-3$ orders of magnitude lower than typical values reported for European urban areas in winter, and 1-2 orders of magnitude lower than European rural background concentrations. Episodes of elevated levoglucosan concentration lasting from 1 to 6 days were more frequent in winter than in summer and peak values were higher, exceeding $10 \mathrm{ng} \mathrm{m}^{-3}$ at the most.

Concentrations of elemental carbon from biomass burning $\left(\mathrm{EC}_{\mathrm{bb}}\right)$ were obtained by combining measured concentrations of levoglucosan and emission ratios of levoglucosan and EC for wildfires/agricultural fires and for residential wood burning. Neglecting chemical degradation by $\mathrm{OH}$ provides minimum levoglucosan concentrations, corresponding to a mean $\mathrm{EC}_{\mathrm{bb}}$ concentration of $3.7 \pm 1.2 \mathrm{ng} \mathrm{m}^{-3}$ in winter (October-April) and $0.8 \pm 0.3 \mathrm{ng} \mathrm{m}^{-3}$ in summer (MaySeptember), or $8.8 \pm 4.5 \%$ of the measured equivalent black carbon (EBC) concentration in winter and $6.1 \pm 3.4 \%$ in summer. When accounting for chemical degradation of lev-
\end{abstract}

oglucosan by $\mathrm{OH}$, an upper estimate of $31-45 \%$ of $\mathrm{EBC}$ could be attributed to $\mathrm{EC}_{\mathrm{bb}}^{*}\left(\mathrm{EC}_{\mathrm{bb}}\right.$ adjusted for chemical degradation) in winter, whereas no reliable $(<100 \%)$ upper estimate could be provided for summer for the degradation rates applied. Hence, fossil fuel sources appear to dominate the European Arctic BC concentrations in winter, whereas the very wide range obtained for summer does not allow us to conclude upon this for the warm season.

Calculations using the Lagrangian particle dispersion model FLEXPART show that the seasonal variation of the modeled $\mathrm{EC}_{\mathrm{bb}}\left(\mathrm{EC}_{\mathrm{bb}, \mathrm{m}}\right)$ concentration compared relatively well with observationally derived $\mathrm{EC}_{\mathrm{bb}}$ from agricultural fires/wildfires during summer, and residential wood burning in winter. The model overestimates by a factor of 2.2 in winter and 4.4 in summer when compared to the observationally derived mean $\mathrm{EC}_{\mathrm{bb}}$ concentration, which provides the minimum estimate, whereas it underestimates by a factor of 2.3 3.3 in winter and a factor of 4.5 in summer when compared to $\mathrm{EC}_{\mathrm{bb}}^{*}$, which provides the upper estimate. There are indications of too-low emissions of residential wood burning in northern Russia, a region of great importance with respect to observed concentrations of BC in the European Arctic.

\section{Introduction}

The presence of ambient air pollutants in the Arctic has been demonstrated in several studies (e.g., Shaw, 1995). These studies have had a particular focus on the Arctic 
haze phenomenon (Quinn et al., 2007), caused by long-range transport of pollutants from the midlatitudes, leading to elevated concentrations of air pollutants during late winter and early spring. Long-term trend studies show a downward trend in black carbon and sulfate aerosol at the three Arctic sites Alert, Barrow and Zeppelin over the last decade (Hirdman et al., 2010a), which is in line with observed aerosol trends at midlatitudes during the last decades (Murphy et al., 2011; Hand et al., 2012; Torseth et al., 2012). Radiative effects of aerosols, both direct and indirect, are complex (Myhre et al., 2013) and can be quite different in the Arctic compared to elsewhere. Due to the high surface albedo of snow and ice, even weakly absorbing aerosol layers in the Arctic can heat the Earth-atmosphere system (Pueschel and Kinne, 1995). Infrared emissions from the haze can heat the surface during the polar night, and during spring when the solar zenith angle is still large (MacCracken et al., 1986). Furthermore, absorbing aerosols deposited in the polar region can affect the snow and ice albedo and increase the amount of solar radiation absorbed, enforcing melting of snow on tundra and sea ice (Clarke and Noone, 1985; Hansen and Nazarenko, 2004). Consequently, it can be argued that the largest uncertainties when studying the aerosols' impact on climate in the Arctic are attributed to black carbon (BC) ${ }^{1}$, which is generated by incomplete combustion of fossil fuel and biomass. Due to its short atmospheric lifetime compared to $\mathrm{CO}_{2}$ it has been suggested that reducing emissions of BC is an effective strategy, complementing $\mathrm{CO}_{2}$ mitigation, to slow global warming in the near future (Bond, 2007; Hansen et al., 2000; Jacobson, 2002; Shindell et al., 2012). It is thus essential to increase current knowledge of the relative strengths of different BC sources in order to implement effective mitigation steps.

Some recent studies have argued that boreal wildfires with their high emissions and proximity to the Arctic could be the most important source of Arctic BC in seasons of high wildfire activity (Stohl, 2006; Stohl et al., 2007; Warneke et al., 2009). Furthermore, an increased frequency of boreal forest fires has been postulated as a consequence of global warming, augmenting its present source strength. Also agricultural fires were identified as a strong episodic source of BC for the

\footnotetext{
${ }^{1}$ Here, the term black carbon $(\mathrm{BC})$ is used according to the recommendations of Petzold et al. (2013). BC is defined as a substance with the following properties: (1) consists of mainly $\mathrm{sp}^{2}$ bonded, graphitic carbon; (2) consists of aggregates of carbon spherules of $10-50 \mathrm{~nm}$ diameter; (3) refractory, volatile at near $4000 \mathrm{~K}$, volatilization by oxidation from $613 \mathrm{~K}$; (4) insoluble in organic solvents and water; (5) strongly absorbing for visible light. There exists no measurement method that is sensitive to all these properties at the same time, i.e., no method for uniquely measuring $\mathrm{BC}$, and $\mathrm{BC}$ only. Therefore, the term $\mathrm{BC}$ is used in a qualitative manner. Only certain BC properties can be quantified, e.g., the absorption coefficient $\sigma_{\mathrm{ap}}$; the equivalent black carbon (EBC) concentration, obtained by multiplying $\sigma_{\text {ap }}$ with an assumed mass absorption coefficient; or the elemental carbon (EC) concentration, obtained by thermal-optical analysis.
}

Arctic (Stohl et al., 2007; Warneke et al., 2009). Warneke et al. (2009) argued that in spring biomass burning (BB) plumes on average contribute at least $80 \%$ as much BC to the Arctic atmospheric burden as is otherwise present as an Arctic background from all sources. However, Brock et al. (2011) have shown that the $\mathrm{BB}$ layers were present only above the sea-ice inversion layers and thus may not regularly be seen at Arctic surface sites.

Countries bordering the Arctic - i.e., the Scandinavian countries, Canada, USA and Russia - are known to use substantial amounts of wood for residential heating; e.g., residential wood burning accounts for more than $60 \%$ (https: //www.ssb.no) of the Norwegian $\mathrm{PM}_{2.5}$ emissions, of which BC is likely to constitute 20-30\% (Yttri et al., 2009). Due to the proximity to the Arctic, BC emissions from these countries are disproportionally important with respect to the Arctic BC contribution compared to emission sources situated further south (Hirdman et al., 2010b). Also, there is a growing number of papers demonstrating that residential wood burning is more widespread and contributes more to the ambient PM, and BC, level in continental Europe than previously assumed (e.g., Sillanpää et al., 2006; Gelencsér et al., 2007; Puxbaum et al., 2007; Lanz et al., 2010; Maenhaut et al., 2012; Genberg et al., 2013). Projections made by the International Atomic Energy Agency (2008) show that the consumption of biomass is likely to increase by approximately $200 \%$ between 2000 and 2020, in order to compensate for reductions in the use of fossil fuels.

Levoglucosan is a thermal degradation product of cellulose and a unique tracer of particulate matter emissions from biomass burning. The component possesses features which make it suitable to trace biomass burning aerosols in the ambient atmosphere; this includes in particular a high emission factor and a low vapor pressure (Locker, 1988; Simoneit et al., 1999; Oja and Sudberg, 1999). The studies by Locker (1988) and Fraser and Lakshmanan (2000) long provided the basis for levoglucosan being stable in the atmosphere for a time period extending up to 10 days. However, more recent indications of degradation of levoglucosan have been inferred from ambient measurements (e.g., Gao et al., 2003; Saarikoski et al., 2007), as well as demonstrated in a few recent laboratory studies (Hennigan et al., 2010; Hoffmann et al., 2010). In particular, aqueous-phase reaction with $\mathrm{OH}$ radical in deliquescent particles appears to be the most efficient pathway causing depletion of levoglucosan in the atmosphere. For example, Hoffmann et al. (2010) found $\tau_{1 / 2}$ values (the time until half of the levoglucosan has been degraded) for levoglucosan ranging from 12.7 to $83.2 \mathrm{~h}$ in a model study representative of polluted continental plume conditions, where the variability in $\tau_{1 / 2}$ reflected variations in photochemical activity and $\mathrm{OH}$ concentrations, being a function of temperature and season. However, confirmation of the range of $\tau_{1 / 2}$ values reported by Hoffmann et al. (2010) for wood burning particles in the atmosphere is still missing. 


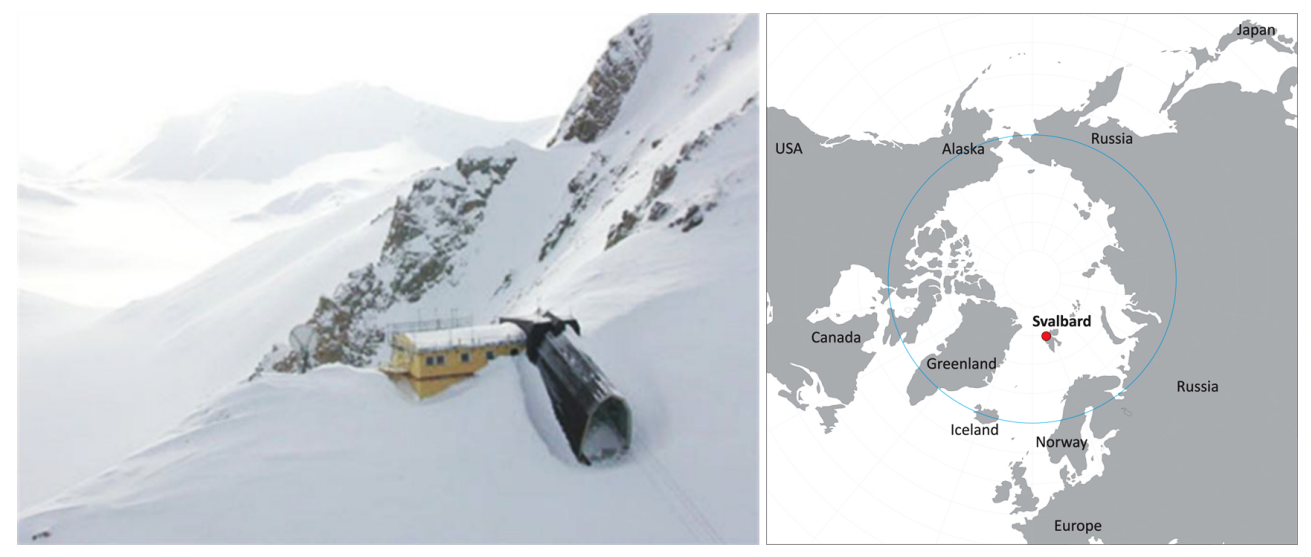

Figure 1. The Zeppelin observatory located at the Zeppelin Mountain ( $478 \mathrm{~m}$ a.s.1.) close to Ny-Ålesund (Svalbard) $\left(78^{\circ} 54^{\prime} \mathrm{N}, 11^{\circ} 53^{\prime} \mathrm{E}\right)$. The light-blue line on the map shows the Arctic Circle.

Although levoglucosan appears to be best suited to trace biomass burning emissions in winter and on a local to regional scale, conservative estimates of the biomass burning aerosol concentration can still be provided for the remote environment. At present there are only very few studies reporting levoglucosan concentrations for the Arctic environment (Stohl et al., 2006, 2007; Fu et al., 2009; von Schneidemesser et al., 2009; Zangrando et al., 2013) and typically for a short duration, days to a few months, and with a low time resolution (48 to $168 \mathrm{~h}$ ). Thus, a time series of levoglucosan including all seasons and with an improved time resolution is needed to get an overview of the current biomass burning aerosol concentration in the Arctic. The presence of levoglucosan in the Arctic has been associated with boreal forest fires (Stohl et al., 2006), agricultural waste burning (Stohl et al., 2007), and closed combustion of wood (Hegg et al., 2009), but no attempt has been made to convert the ambient aerosol levels of levoglucosan into levels of carbonaceous aerosol, e.g., BC, from these respective sources.

The current study presents the first one-year time series of levoglucosan in the Arctic environment, and allows for a quantification of the BC fraction of the aerosol in the Arctic originating from agricultural and wildfires during summer, and from residential wood burning during winter.

\section{Experimental}

\subsection{Site description and measurement period}

Aerosol filter samples were collected at the Zeppelin atmospheric observatory $\left(78^{\circ} 54^{\prime} \mathrm{N}, 11^{\circ} 53^{\prime} \mathrm{E}, 478 \mathrm{~m}\right.$ a.s.l.) (Fig. 1) outside Ny-Ålesund at the west coast of the Spitsbergen island in the Svalbard archipelago (Norway). The samples were collected during the one-year period from 12 March 2008 to 7 March 2009. The Zeppelin observatory is an important site in various global, regional and national monitoring networks, including the European Evaluation and Mon- itoring Programme (EMEP), the Global Atmospheric Watch (GAW) and the Arctic Monitoring and Assessment Programme (AMAP). The site is also included in the EU infrastructure project ACTRIS (Aerosols, Clouds and Trace gases Research InfraStructure Network).

\subsection{Aerosol filter sampling for analysis of levoglucosan}

Ambient aerosol filter samples subjected to levoglucosan analysis were obtained using a Digitel high-volume sampler equipped with a $\mathrm{PM}_{10}$ inlet, collecting aerosols on prefired $\left(850^{\circ} \mathrm{C} ; 3 \mathrm{~h}\right.$ ) quartz fiber filters (Munktel MK360; $150 \mathrm{~mm}$ in diameter, batch number 11415138). The sampler was operated at a flow rate of $20 \mathrm{~m}^{3} \mathrm{~h}^{-1}$. The sampling time was $24 \mathrm{~h}$. The sampling inlet was installed approximately $2 \mathrm{~m}$ above the roof level of the observatory and $5 \mathrm{~m}$ above the ground level.

For certain days throughout the sampling period the Digitel sampler was not operational; hence filter samples were obtained from a co-located high-volume sampler with a $\mathrm{PM}_{2.5}$ inlet collecting aerosols on $8^{\prime \prime} \times 10^{\prime \prime}$ cellulose filters (Whatman 41) according to a $2+2+3$-day weekly sampling scheme. The sampler was operated at a flow rate of $1.1 \mathrm{~m}^{3} \mathrm{~h}^{-1}$. Post-exposure and prior to analysis the filter samples were wrapped in aluminium foil, placed in polyethylene zip lock bags, and stored in a freezer $\left(-18^{\circ} \mathrm{C}\right)$. One field blank was assigned to each month of sampling and was treated in exactly the same manner regarding preparation, handling, transport and storage as the filters being exposed, except that they were not inserted in the sampler.

Quality assurance of the aerosol filter sampling, as well as the chemical analysis performed, are presented in Sect. 3.

\subsection{Measurement of levoglucosan, mannosan and galactosan}

Quantification of the monosaccharide anhydrides (MAs) levoglucosan, mannosan and galactosan was performed 
according to the method described by Dye and Yttri (2005), and is only briefly described here.

Between 50 and $100 \%\left(77-154 \mathrm{~cm}^{2}\right)$ of the quartz fibre filter were soaked in tetrahydrofuran $(10 \mathrm{~mL})$ and subjected to ultrasonic agitation $(30 \mathrm{~min})$. The filter extract was filtered through a syringe filter $(0.45 \mu \mathrm{m})$ to remove insoluble PM and filter parts. Each filter was extracted twice. The extracted volumes were pooled and evaporated to a total volume of $1 \mathrm{~mL}$ in an $\mathrm{N}_{2}$ atmosphere. Before analysis the sample solvent elution strength was adapted to the mobile phase by adding Milli-Q water $(0.8 \mathrm{~mL})$. The concentrations of MAs were determined using high-performance liquid chromatography (HPLC) in combination with HRMSTOF (high-resolution mass spectrometry-time of flight) operated in the negative electrospray mode. The compound separation was performed with two series-connected reversedphase C18 columns (Atlantis dC18, Waters). Levoglucosan, mannosan and galactosan were identified and quantified on the basis of retention time and mass spectra of authentic standards (Sigma). ${ }^{13} \mathrm{C}$ labeled levoglucosan $\left(\mathrm{C}_{6} \mathrm{H}_{10} \mathrm{O}_{5}\right)$ and galactosan $\left(\mathrm{C}_{6} \mathrm{H}_{10} \mathrm{O}_{5}\right)$, purchased from Cambridge Isotope Laboratories, Inc., were used as internal standards. This approach accounts for any potential loss of the native compounds during the sample preparation.

\subsection{Measurement of black carbon (BC)}

The concentration of light-absorbing particles was measured using a particle soot absorption photometer (PSAP). In this instrument, light ( $522 \mathrm{~nm}$ wavelength) illuminates two $3 \mathrm{~mm}$ diameter spots on a single filter substrate, on one of which particles are collected from ambient air flushed through the filter, while the other is flushed with the same amount of particle-free air for respect. The particle light absorption coefficient $\sigma_{\mathrm{ap}}$ is derived from the change in light transmittance across the filter. The influence of particle scattering has been corrected according to Bond et al. (1999). Assuming that all the light absorption measured is due to $\mathrm{BC}$ and that all $\mathrm{BC}$ has the same light absorption efficiency, $\sigma_{\text {ap }}$ values can be converted to equivalent $\mathrm{BC}$ (EBC) mass concentrations when divided by the mass absorption cross section $(\alpha)$. For the $\alpha$ value used to calculate EBC in the present study, see Sect. 2.7.

\subsection{Measurements of elemental, organic and total carbon}

Total carbon (TC), elemental carbon (EC) and organic carbon (OC) were quantified using the thermal-optical transmittance (TOT) instrument from Sunset Laboratories Inc., which corrects for charring of OC during analysis (Birch and Cary, 1996). The instrument was operating according to the EUSAAR_2 protocol (Cavalli et al., 2010).
Table 1. Equations used to calculate concentrations of $\mathrm{EC}_{\mathrm{bb}}$.

$$
\begin{aligned}
& \mathrm{TC}_{\mathrm{bb}}=[\mathrm{LG}] \times(\mathrm{TC} / \mathrm{LG})_{\mathrm{bb}}(1) \\
& \mathrm{OC}_{\mathrm{bb}}=\mathrm{TC}_{\mathrm{bb}} \times(\mathrm{OC} / \mathrm{TC})_{\mathrm{bb}}(2) \\
& \mathrm{EC}_{\mathrm{bb}}=\mathrm{TC}_{\mathrm{bb}}-\mathrm{OC}_{\mathrm{bb}}(3) \\
& \text { Square brackets denote measured quantities. } \\
& \text { Parentheses denote emission ratios (see } \\
& \text { Table 2). } \\
& \text { Notation: } \mathrm{TC}=\text { total carbon; } \\
& \mathrm{LG}=\text { levoglucosan; OC= organic carbon; } \\
& \mathrm{EC}=\text { elemental carbon; subscript } \\
& \mathrm{bb}=\text { biomass burning. }
\end{aligned}
$$

\begin{tabular}{|c|c|c|c|}
\hline & $-\mathrm{SD}$ & Mean & $+\mathrm{SD}$ \\
\hline \multicolumn{4}{|l|}{ Res wood burning $^{1}$} \\
\hline$(\mathrm{TC} / \mathrm{LG})_{\mathrm{bb}}$ & 10.9 & 14.7 & 18.4 \\
\hline$(\mathrm{OC} / \mathrm{TC})_{\mathrm{bb}}$ & 0.73 & 0.78 & 0.82 \\
\hline \multicolumn{4}{|l|}{ Wildfires/agricultural fires ${ }^{2}$} \\
\hline$(\mathrm{TC} / \mathrm{LG})_{\mathrm{bb}}$ & 38 & 48 & 58 \\
\hline$(\mathrm{OC} / \mathrm{TC})_{\mathrm{bb}}$ & 0.80 & 0.85 & 0.90 \\
\hline
\end{tabular}

Table 2. Emission ratios (mean $\pm \mathrm{SD}$ ) used to calculate concentrations of EC from biomass burning (EC $\mathrm{bb}$ ) according to Eqs. (1-3).

1 Yttri et al. $(2009,2011 \mathrm{a})$

${ }^{2}$ Saarikoski et al. (2007)

\subsection{Emission ratios used to calculate $\mathrm{EC}$ from biomass burning $\left(\mathbf{E C}_{\mathbf{b b}}\right)$}

For residential combustion, emission ratios for levoglucosan have been reported, or can be derived, for a wide range of softwood and hardwood trees - see e.g. Fine et al. (2001, 2002a, b, 2004), Mazzoleni et al. (2007) and Simoneit et al. (1999) - but are typically for US tree types, using US appliances. There are only few stove measurements for European tree types, e.g., Puxbaum et al. (2007) and Schmidl et al. (2008). Studies with single appliances show a large variability, owing to different combustion conditions (e.g., Schmidl et al., 2008), different technologies or type of wood used. Studies using ambient data could provide a good alternative, as they reflect the weighted mean of all the factors mentioned above, but results will vary from region to region (Yttri et al., 2009).

The choice of emission ratio is critical for the EC derived from biomass burning $\left(\mathrm{EC}_{\mathrm{bb}}\right)$ emissions. Thus, we have made an effort to select emission ratios from the geographical region being the source region of the Zeppelin observatory, both with respect to emissions from agricultural fires/wildfires and residential wood burning. Emission ratios for levoglucosan with reference to EC, OC and TC are not abundant for the actual region, and we recognize that we thus potentially might miss parts of the total range. However, expanding the range based on ratios from prescribed fires or laboratory burn tests involving vegetation from other parts of the world is scientifically hard to justify. 
To account for the fact that the emission ratio for residential wood burning is likely to differ as a function of e.g. wood type, type of appliance and flaming versus smoldering combustion, and consequently between geographical regions, we have allowed for a rather wide range in our calculations and adopted the range and approach reported by Yttri et al. (2011a) (Tables 1 and 2). Consequently, the analytical method used to determine levoglucosan is self-consistent, as the method by Dye and Yttri (2005) was applied both in the present study as well as in that of Yttri et al. (2009), from which the emission ratio range listed in Yttri et al. (2011a) was derived.

Emission ratios for wildfires and agricultural fires likely have a similarly wide range as those reported for residential wood burning, as the vegetation type being burnt can vary widely. In the present study we derived emission ratios of levoglucosan from the study of Saarikoski et al. (2007), which reported observed concentrations of levoglucosan, EC and $\mathrm{OC}$ at a rural background site in Helsinki during influence of emissions from the major wildfires and agricultural fires that took place in eastern Europe in spring 2006 (see Table 2). A main argument for deriving emission ratios from Saarikoski et al. (2007) is the proximity of Helsinki with respect to the area burnt. Hence, the transport time of the air masses passing over Helsinki from the area burnt causes deposition as well as potential depletion of levoglucosan by $\mathrm{OH}$ still to be moderate. Also the area burnt is considered to be in the subBoreal region and thus ought to be representative for wildfire/agricultural fire emissions impacting the European Arctic. Indeed, emissions from this exact fire event have been reported to reach the European Arctic, causing record high levels of air pollutants (Stohl et al., 2007). Further, the LCMS method used for levoglucosan analysis by Saarikoski et al. (2007) was similar to the method of Dye and Yttri (2005), which was used in the present study, and which also is the basis for the levoglucosan emission ratio used for emissions from residential wood burning.

$\mathrm{EC}_{\mathrm{bb}}$ was calculated using Eqs. (1-3) (see Table 1), using the emission ratios listed in Table 2. Obviously, a mix of emissions from residential wood burning and wildfires/agricultural fires can occur (see Fig. 2d), particularly during the transient periods in spring and fall. In the present study, we have used weighted emission ratios according to the relative contribution of $\mathrm{BC}$ from wildfires/agricultural fires versus BC from residential wood burning, as predicted by the FLEXPART (FLEXible PARTicle dispersion) model. See Section 2.8 for further details on the model runs, and Fig. $2 \mathrm{~d}$ for the time series of $\mathrm{BC}$ associated with wildfires/agricultural fires and residential wood burning as predicted by the FLEXPART model.

\section{$2.7 \alpha$ values for calculation of equivalent black carbon (EBC)}

A challenge when providing a whole-year time series of the relative content of $\mathrm{EC}_{\mathrm{bb}}$ in aerosol at Zeppelin lies in the fact that $\mathrm{EC}_{\mathrm{bb}}$ can be calculated using only the levoglucosan concentration as a proxy, while the (total) EC concentration as a reference is available only in winter. Summertime EC concentrations are below the detection limit of the thermaloptical analysis (TOA) at Zeppelin. To overcome this challenge, the relative $\mathrm{EC}_{\mathrm{bb}}$ concentration is referenced not to the EC concentration, but to the EBC concentration derived from the aerosol absorption coefficient $\sigma_{\text {ap }}$ by employing a mass absorption cross-section $\alpha$. The calculation is tied to the EC concentrations measured at Zeppelin by calculating a site-specific $\alpha$ using the concurrent measurements of $\sigma_{\text {ap }}$ and $\mathrm{EC}$ in winter:

$\alpha=\sigma_{\mathrm{ap}} / \mathrm{EC}$.

Deriving the relative $\mathrm{EC}_{\mathrm{bb}}$ concentration, $\mathrm{EC}_{\mathrm{bb}, \mathrm{rel}}$, is then straightforward:

$$
\begin{aligned}
& \mathrm{EC}_{\mathrm{bb}, \text { rel }}=\mathrm{EC}_{\mathrm{bb}} / \mathrm{EBC} \\
& =[\mathrm{LG}](\mathrm{TC} / \mathrm{LG})_{\mathrm{bb}}\left(1-(\mathrm{OC} / \mathrm{TC})_{\mathrm{bb}}\right) / \sigma_{\mathrm{ap}} / \alpha,
\end{aligned}
$$

where [LG] denotes the levoglucosan concentration, and the emission ratios $(\mathrm{TC} / \mathrm{LG})_{\mathrm{bb}}$ and $(\mathrm{OC} / \mathrm{TC})_{\mathrm{bb}}$ the sourcespecific emission ratios taken from Yttri et al. (2011a) in winter and Saarikoski et al. (2007) in summer (see Table 2). We obtain a site- and season-specific $\alpha$ value of $5.7 \pm 2.3 \mathrm{~m}^{2} \mathrm{~g}^{-1}$ for the Zeppelin observatory in winter. The number of samples $(n=35)$ from which the $\alpha$ value was derived was limited by the low ambient EC levels and the detection limit of the thermal-optical instrument (see Sect. 3). In the absence of any other more specific information, the same $\alpha$ value is used for summer as well. $r^{2}$ was 0.77 when correlating EC and $\sigma_{\text {ap }}$.

The $\alpha$ value obtained and applied in the current study is substantially lower than that used for Arctic sites by Sharma et al. (2013), but consistent with that applied by Hegg et al. (2011) for Svalbard. Various instruments, operating at different wavelengths, likely explain most of the variability.

\subsection{FLEXPART model simulations}

$\mathrm{BC}$ concentrations and source receptor relationships were simulated with the Lagrangian particle dispersion model FLEXPART (Stohl et al., 1998, 2005; Stohl and Thomson, 1999) using 3-hourly operational meteorological analyses from the European Centre for Medium-Range Weather Forecasts (ECMWF) with 91 model levels and a horizontal resolution of $1 \times 1$ degrees. For each levoglucosan measurement carried out at Zeppelin 50000 particles were released and

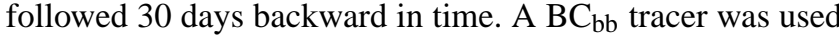
that is subject to dry and wet deposition. The model set-up 


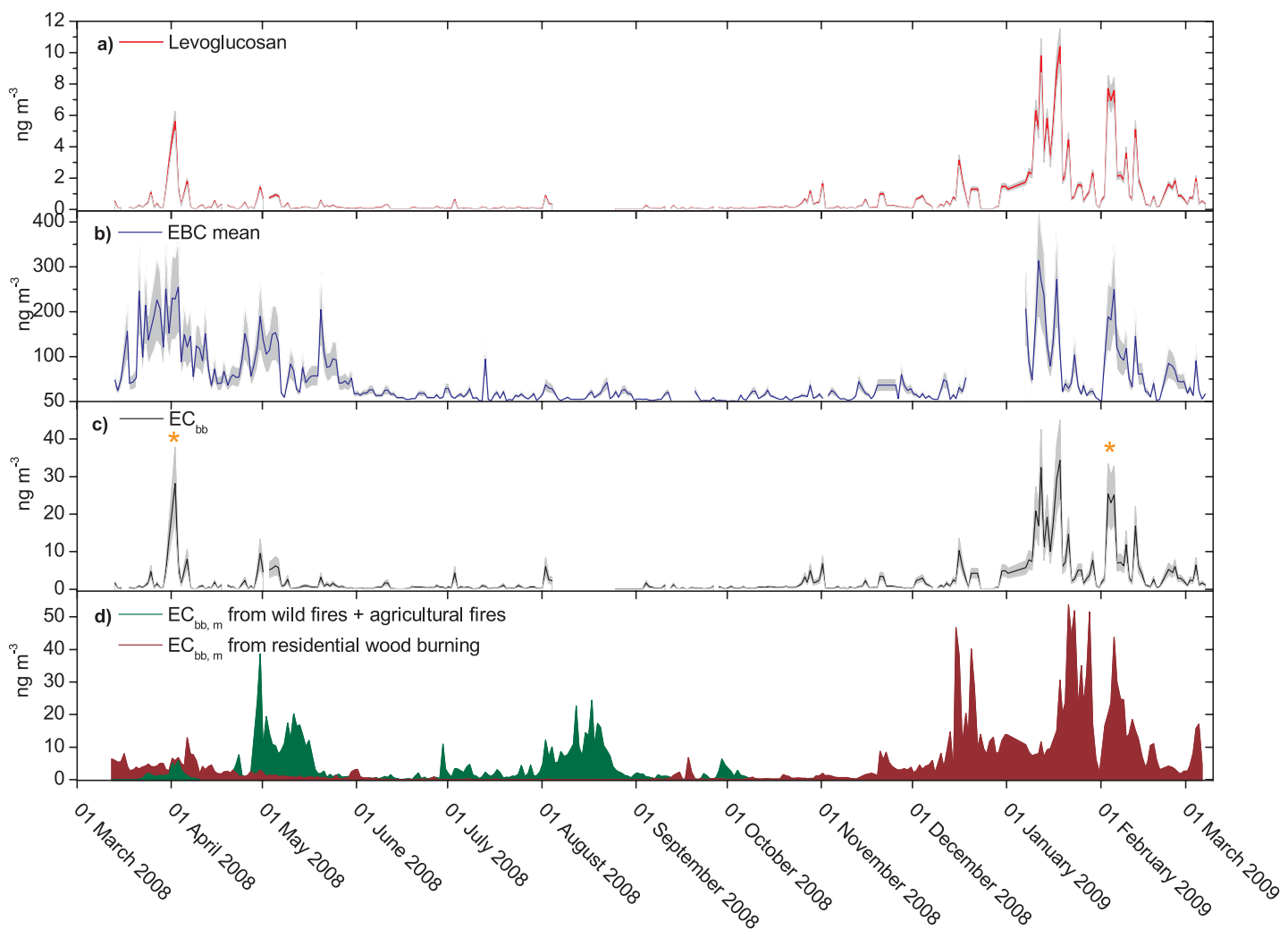

Figure 2. Ambient aerosol concentrations of levoglucosan (a), equivalent black carbon (EBC) (b) and elemental carbon from biomass burning $\left(\mathrm{EC}_{\mathrm{bb}}\right)(\mathbf{c})$, presented as $24 \mathrm{~h}$ mean concentrations for the Zeppelin observatory during the period 12 March $2008-7$ March 2009. (d) shows modeled concentrations of $\mathrm{EC}_{\mathrm{bb}}\left(\mathrm{EC}_{\mathrm{bb}, \mathrm{m}}\right)$, as obtained by the FLEXPART model. The green curve is the sum of EC from wildfires and agricultural fires, whereas the red curve is EC from residential wood burning. The two orange asterisks in (c) indicate episodes with a rapid increase in the $\mathrm{EC}_{\mathrm{bb}}$ concentration that are not captured well by the model and which are discussed in further detail in Sect. 4.4.

and the parameters used for the $\mathrm{BC}_{\mathrm{bb}}$ tracer were identical to the BC tracer simulations described by Stohl et al. (2013). However, for the $\mathrm{BC}_{\mathrm{bb}}$ tracer we only considered $\mathrm{BC}$ emissions from residential wood burning, wildfires and agricultural fires (see below).

The experimental determination of $\mathrm{EC}_{\mathrm{bb}}$ according to Eqs. (1)-(3) assumes that levoglucosan is not chemically degraded in the atmosphere. However, in reality the levoglucosan chemical half-life time $\tau_{1 / 2}$ may range from 12.7 to 83.2 $\mathrm{h}$ according to Hoffmann et al. (2010). To explore the impact of such degradation on modeled $\mathrm{BC}_{\mathrm{bb}}$ concentrations, chemical decay following a number of different halflife times $(0.5,1,2,3,4$ and 5 days) was superimposed on the other BC loss processes (i.e., dry deposition and wet scavenging) (see Table 3). The differences to simulated $\mathrm{BC}_{\mathrm{bb}}$ without decay allow quantifying the impact of this process.

The estimate of emissions from residential wood burning and open burning of agricultural residues used in this study have been developed with the GAINS (Greenhouse gas-Air pollution Interactions and Synergies) model (Amann, 2011; see http://gains.iiasa.ac.at) within the ECLIPSE (Evaluating the CLimate and Air Quality ImPacts of ShortlivEd Pol- lutants) project. More detailed description is provided in Klimont et al. (2013) and Kupiainen and Klimont (2007), and gridded emission data sets are available through the ECLIPSE project website (http://eclipse.nilu.no) upon request. Open biomass burning (forest and savannah fires) emissions originate from the Global Fire Emissions Database (GFED) version 3.1 (van der Werf et al., 2010).

\section{Quality assurance}

Sampling was conducted for a time period of 352 days, of which 321 days were covered by the sampling. The mismatch between the two numbers was typically attributed to instrument malfunction. In total 289 filter samples were collected. For some filters the sampling time extended beyond $24 \mathrm{~h}$ because poor weather conditions prevented the engineers to access the station. Certain filter samples were considered unacceptable for analyses because they were soaking wet from snow entering the inlet during harsh weather conditions. Moreover, during occasions when the Digitel sampler was not operational due to e.g. maintenance, filter samples were obtained from a co-located high-volume sampler, with 
Table 3. Modeled $\left(\mathrm{EC}_{\mathrm{bb}, \mathrm{m}}\right)$, observationally derived $\left(\mathrm{EC}_{\mathrm{bb}}\right)$ and chemical-lifetime-corrected $\left(\mathrm{EC}_{\mathrm{bb}}^{*}\right)$ mean concentrations of $\mathrm{EC}$ assuming chemical half-life times $\left(\tau_{1 / 2}\right)$ of levoglucosan ranging from $12 \mathrm{~h}$ to 5 days and relative contribution of $\mathrm{EC}_{\mathrm{bb}}^{*}$ to $\mathrm{EBC}_{\text {. }}$

\begin{tabular}{|c|c|c|c|}
\hline & $\mathrm{EC}_{\mathrm{bb}}\left(\mathrm{ng} \mathrm{m}^{-3}\right)$ & $\mathrm{EC}_{\mathrm{bb}}^{*}\left(\mathrm{ng} \mathrm{m}^{-3}\right)$ & $\mathrm{EC}_{\mathrm{bb}}^{*} / \mathrm{EBC}(\%)$ \\
\hline \multicolumn{4}{|l|}{ Winter } \\
\hline $\mathrm{EC}_{\mathrm{bb}}\left([\text { Levo }]^{*}\right.$ ER) Observed & 3.9 & & \\
\hline $\mathrm{EC}_{\mathrm{bb}, \mathrm{m}} \operatorname{Mod}$ (Dry/Wet dep.) & 8.5 & & \\
\hline $\mathrm{EC}_{\mathrm{bb}, \mathrm{m}}$ Mod (Dry/Wet dep.) Life t. 0.5 & 0.03 & 1203 & 1908 \\
\hline $\mathrm{EC}_{\mathrm{bb}, \mathrm{m}} \operatorname{Mod}$ (Dry / Wet dep.) Life t. 1 & 0.18 & 181 & 286 \\
\hline $\mathrm{EC}_{\mathrm{bb}, \mathrm{m}} \operatorname{Mod}$ (Dry / Wet dep.) Life t. 2 & 0.67 & 50 & 72 \\
\hline $\mathrm{EC}_{\mathrm{bb}, \mathrm{m}} \operatorname{Mod}$ (Dry / Wet dep.) Life t. 3 & 1.2 & 28 & 45 \\
\hline $\mathrm{EC}_{\mathrm{bb}, \mathrm{m}}$ Mod (Dry / Wet dep.) Life t. 4 & 1.7 & 20 & 31 \\
\hline $\mathrm{EC}_{\mathrm{bb}, \mathrm{m}}$ Mod (Dry / Wet dep.) Life t. 5 & 2.1 & 15 & 25 \\
\hline \multicolumn{4}{|l|}{ Summer } \\
\hline $\mathrm{EC}_{\mathrm{bb}}\left([\text { levo }]^{*} \mathrm{ER}\right)$ Observed & 0.91 & & \\
\hline $\mathrm{EC}_{\mathrm{bb}, \mathrm{m}} \operatorname{Mod}($ Dry / Wet dep) & 4.0 & & \\
\hline $\mathrm{EC}_{\mathrm{bb}, \mathrm{m}} \operatorname{Mod}$ (Dry / Wet dep.) Life t. 0.5 & 0.001 & 4672 & 16556 \\
\hline $\mathrm{EC}_{\mathrm{bb}, \mathrm{m}} \operatorname{Mod}$ (Dry / Wet dep.) Life t. 1 & 0.004 & 802 & 2843 \\
\hline $\mathrm{EC}_{\mathrm{bb}, \mathrm{m}} \operatorname{Mod}$ (Dry / Wet dep.) Life t. 2 & 0.03 & 123 & 436 \\
\hline $\mathrm{EC}_{\mathrm{bb}, \mathrm{m}}$ Mod (Dry / Wet dep.) Life t. 3 & 0.09 & 39 & 139 \\
\hline $\mathrm{EC}_{\mathrm{bb}, \mathrm{m}}$ Mod (Dry / Wet dep.) Life t. 4 & 0.20 & 18 & 65 \\
\hline $\mathrm{EC}_{\mathrm{bb}, \mathrm{m}}$ Mod (Dry / Wet dep.) Life t. 5 & 0.33 & 11 & 39 \\
\hline
\end{tabular}

$\mathrm{ECbb}^{*}=\mathrm{ECbb}$ adjusted with respect to lifetime/degradation as predicted by the FLEXPART model.

a sampling time of 2 (Monday-Wednesday and WednesdayFriday) and 3 (Friday-Monday) days per week.

In total 106 samples were collected during summertime (May-September) sampling, whereas the corresponding number for winter (October-April) was 183.

Aerosol particles emitted from biomass burning are found to reside in the fine particle size fraction (e.g., Kleeman et al., 1999; Hedberg et al., 2006; Yttri et al., 2005). Hence, we regard the $\mathrm{PM}_{2.5}$ cut-off size of the co-located high-volume sampler, which was used when the Digitel high-volume sampler ( $\mathrm{PM}_{10}$ inlet) was out of order due to maintenance, as a minor uncertainty.

The HPLC/HRMS-TOF methodological limit of detection (LOD) for levoglucosan, mannosan and galactosan at a signal-to-noise ratio of 3 was $7.5 \mathrm{pg} \mathrm{m}^{-3}$. A total of $97 \%$ of the samples contained levoglucosan at levels exceeding the LOD. Concurrent data of the isomeric compounds mannosan and galactosan were available for only $30 \%$ of the samples, due to their low observed levels. Levoglucosan was the most abundant isomer, accounting for $79 \pm 6.4 \%$ of the sum of the three isomers, which is comparable to what has been reported in the literature for areas impacted by biomass burning (e.g., Zdrahal et al., 2002; Yttri et al., 2011b). When calculating mean concentrations, values below the detection limit were accounted for by using a value corresponding to one-half of the LOD. The precision was found to be satisfactory, with a relative standard deviation below $5 \%$. The quartz fiber filters field blanks did not contain monosaccharide anhydrides, while the cellulose filters contained $30 \mathrm{pg}$ of levoglucosan per filter, which was accounted for when performing the calculations.

Thermal-optical analysis of EC, OC and TC was conducted for a selection of samples only $(n=73)$, i.e., for the filter samples experiencing the highest concentration of levoglucosan and/or filters which showed visual sign of coloring. Twelve of the filter samples subjected to TOA were picked from the period 20 March to 25 April 2008, whereas the remaining filter samples were from the period 18 November 2008 to 7 March 2009. In total $10 \%$ of the filter samples had TC concentrations below the TOA analytical detection of $0.2 \mu \mathrm{g} \mathrm{C} \mathrm{cm}{ }^{-2}$, whereas the corresponding percentage for EC was $45 \%$. Field blanks $(n=2)$ analyzed within 10 months after the sampling period was ended showed remarkably low carbon concentrations, i.e., $<0.2 \mu \mathrm{g} \mathrm{C} \mathrm{cm}{ }^{-2}$ being the analytical LOD of the TOA instrument. The carbon content of field blanks $(n=6)$ analyzed after 5 years was $1.0 \pm 0.3 \mu \mathrm{g} \mathrm{cm}^{-2}$. For the one field blank for which reanalysis was possible, the concentration increased from $0.1 \mu \mathrm{g} \mathrm{C} \mathrm{cm}{ }^{-2}$, which is below the instrument's analytical LOD, to $0.73 \mu \mathrm{g} \mathrm{cm}^{-2}$, strongly suggesting that the field blanks have picked up organic material during 5 years of storage in the freezer at $-18^{\circ} \mathrm{C}$. For all field blanks, the carbon content was entirely attributed to OC; i.e., no EC was observed on the field blanks. The sampling approach did not allow for addressing positive and negative artifacts associated with sampling of OC. 
a) Summer (May-Sept)

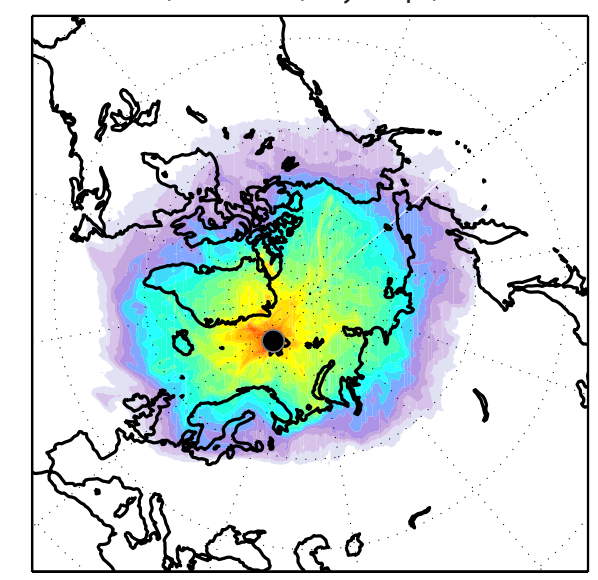

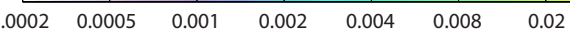

b) Winter (Oct-April)

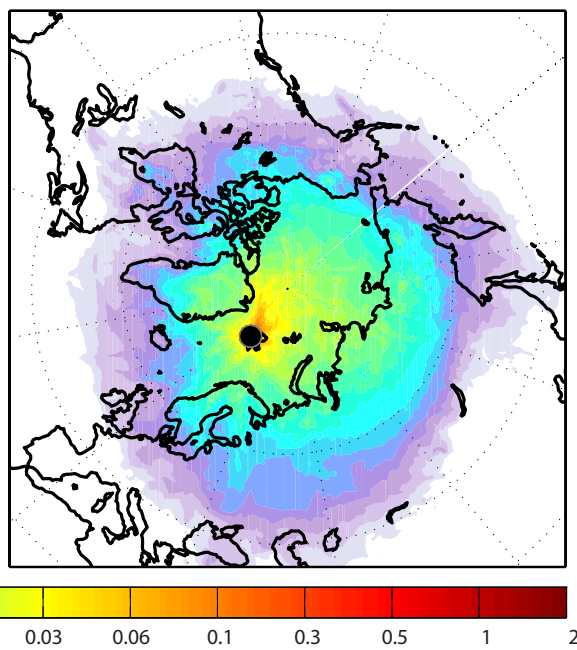

Figure 3. The overall emission sensitivity of measurements at the Zeppelin observatory to surface emissions during the last 30 days of air transport to the site for summer (here: mean of June-August, 2008) (a) and winter (here: mean of January-March, 2009) (b), respectively. Unit: $\mathrm{ns} \mathrm{m}^{-3}$.

\section{Results and discussion}

\subsection{Levels of levoglucosan}

Ambient concentrations of levoglucosan observed at the Zeppelin observatory during the period 12 March 2008-7 March 2009 are shown in Fig. 2 (panel a). The annual mean concentration of levoglucosan was $0.68 \mathrm{ng} \mathrm{m}^{-3}$. Elevated concentrations in winter (October-April) (mean $1.02 \mathrm{ng} \mathrm{m}^{-3}$ ) compared to summer (May-September) (mean $0.13 \mathrm{ng} \mathrm{m}^{-3}$ ) were observed, resembling the well-known seasonal pattern seen for e.g. sulfate and BC caused by the Arctic haze phenomenon (Shaw, 1995). The wintertime mean concentration of levoglucosan at the Zeppelin observatory was $2-3$ orders of magnitude less than typical concentrations reported for European urban areas in winter (Szidat et al., 2009), and 12 orders of magnitude less than that of the European rural background environment (Puxbaum et al., 2007; Yttri et al., 2014). The very few studies reporting levoglucosan concentrations for the Arctic environment - i.e., Stohl et al. (2006, 2007) and Zangrando et al. (2013) for the Zeppelin observatory, Fu et al. (2009) for Alert (Canada), Schneidemesser et al. (2009) for Summit (Greenland) and Fu et al. (2013) for the Beaufort Sea (Canada) - have found levels within the concentration range reported in the present study. The daily maximum concentration of $10.4 \mathrm{ng} \mathrm{m}^{-3}$ was observed on 17-18 January 2009 and is more than 3 times higher than the concentration reported by Stohl et al. (2007) $\left(3.2 \mathrm{ng} \mathrm{m}^{-3}\right)$ during the severe air pollution episode caused by agricultural fires in eastern Europe affecting the European Arctic in spring 2006.

The highest monthly mean concentration of levoglucosan was observed for January $\left(3.2 \mathrm{ng} \mathrm{m}^{-3}\right)$, which along with February $\left(2.0 \mathrm{ng} \mathrm{m}^{-3}\right)$ were the only two months for which the mean concentration exceeded $1.0 \mathrm{ng} \mathrm{m}^{-3}$. The lowest monthly mean was observed for September $\left(0.07 \mathrm{ng} \mathrm{m}^{-3}\right)$.

The ambient concentration of levoglucosan (Fig. 2, panel a) showed minor variability during summertime sampling with only two episodes of elevated levoglucosan levels. The maximum $24 \mathrm{~h}$ concentrations increased by a factor of $7-$ 11 compared to the summertime mean $\left(0.13 \mathrm{ng} \mathrm{m}^{-3}\right)$ during these episodes. During winter, episodes of elevated levoglucosan concentration were more frequent than in summer. Peaks of similar magnitude as seen during summer were observed regularly from the middle of October on. From the start of December until the end of the sampling period (7 March), the levoglucosan time series was characterized by several episodes and periods of considerably elevated concentrations, one of which extended up to 2.5 weeks' duration in January. The $24 \mathrm{~h}$ maximum levoglucosan concentration for the entire year of sampling was observed during this period, exceeding $10 \mathrm{ng} \mathrm{m}^{-3}$, hence being 1 order of magnitude higher than the wintertime mean $\left(1.02 \mathrm{ng} \mathrm{m}^{-3}\right)$. The wintertime sampling period also included the months March and April in 2008, and a major peak in the transition between March and April is evident.

\subsection{Main source regions contributing to elevated levoglucosan concentrations at the Zeppelin observatory}

To identify the main source regions of the observed levoglucosan concentrations at the Zeppelin observatory we have used the FLEXPART model (see Sect. 2.8) to calculate the emission sensitivity of BC tracer aerosols for the summer and winter months. Figure 3 shows the overall sensitivity of measurements at the Zeppelin observatory to surface emissions 
during the last 30 days of air transport to the site for summer (panel a) and winter (panel b), respectively. High values show where the air mass has been in contact with the surface for a long time (unit: $\mathrm{ns} \mathrm{m}^{-3}$ ), and consequently has the greatest potential to take up emissions. Hence, the plots indicate where potential surface sources influence the measurements. There is a clear seasonal variation in the BC emission sensitivity. During winter (panel b), relatively high values extend towards northern Eurasia, and as far south as approximately $50^{\circ} \mathrm{N}$, covering large parts of Russia, Scandinavia and eastern Europe. This is expected to be the most important source region for BC during wintertime at Zeppelin. During summer (panel a), high values are limited to the Arctic Ocean basin and the emission sensitivity decreases distinctly from the northern continental coastline and southward. This indicates that $\mathrm{BC}$ aerosol particles emitted at the relatively warmer landmasses at lower latitudes are less likely to reach the Zeppelin observatory on a 30-day timescale during the summer season. Consequently, sources located in the central European and Eurasian region are less likely to have a direct impact on the measurements during summer than during winter. This is consistent with the current understanding of atmospheric transport patterns in the Arctic (Hirdman et al., 2010b, and references therein).

\subsection{Levels of equivalent carbon (EBC) and $\mathrm{EC}$ from biomass burning $\left(\mathbf{E C}_{\mathbf{b b}}\right)$}

Ambient concentrations of $\mathrm{EBC}$ and $\mathrm{EC}_{\mathrm{bb}}$ at the Zeppelin observatory during the one-year sampling period are shown in Fig. 2, panel b and panel c, respectively. The annual mean concentration of EBC was $46 \pm 19 \mathrm{ng} \mathrm{m}^{-3}$ (Mean \pm SD), which compares well with the annual mean of EBC (39 $\mathrm{ng} \mathrm{m}^{-3}$ ) for Zeppelin for the time period 1998-2007, reported by Eleftheriadis et al. (2009). It should be noted that a different instrument (aethalometer), wavelength $(\lambda=$ $880 \mathrm{~nm})$ and absorption cross section $\left(\alpha=15.9 \mathrm{~m}^{2} \mathrm{~g}^{-1}\right)$ were used by Elefteriadis et al. (2009) than in the present study. The seasonal variation observed in the present study was similar to that of Elefteriadis et al. (2009), with increased concentrations in winter $\left(63 \pm 26 \mathrm{ng} \mathrm{m}^{-3}\right)$ (October-April) compared to summer $\left(25 \pm 10 \mathrm{ng} \mathrm{m}^{-3}\right)$ (May-September), with monthly mean concentrations ranging from a maximum in March $\left(113 \pm 45 \mathrm{ng} \mathrm{m}^{-3}\right)$ to a minimum in September $\left(5.4 \pm 2.2 \mathrm{ng} \mathrm{m}^{-3}\right)$. Major peaks of $\operatorname{EBC}\left(>100 \mathrm{ng} \mathrm{m}^{-3}\right)$ were exclusively observed during the wintertime period.

The annual mean concentration of $\mathrm{EC}_{\mathrm{bb}}$ was $2.6 \pm 0.8 \mathrm{ng} \mathrm{m}^{-3}$. The seasonal variation, showing elevated concentrations in winter $\left(3.7 \pm 1.2 \mathrm{ng} \mathrm{m}^{-3}\right)$ compared to summer $\left(0.8 \pm 0.3 \mathrm{ng} \mathrm{m}^{-3}\right)$, as well as frequency and evolution of episodes, equals that of levoglucosan as $\mathrm{EC}_{\mathrm{bb}}$ is merely a function of the observed concentration of levoglucosan and a given emission ratio. The highest monthly mean was observed for January $\left(11 \pm 3.4 \mathrm{ng} \mathrm{m}^{-3}\right)$ and the lowest for September $\left(0.5 \pm 0.2 \mathrm{ng} \mathrm{m}^{-3}\right) . \quad \mathrm{EC}_{\mathrm{bb}}$ concentrations exceeding $20 \mathrm{ng} \mathrm{m}^{-3}$ on a daily basis were only observed for $2.5 \%$ of the samples and were all confined within the wintertime period.

No pronounced correlation was observed between the absorption coefficient $\left(\sigma_{\mathrm{ap}}\right)$ and levoglucosan on an annual basis; hence BC from other sources than biomass burning was likely the major contributor to the observed absorption coefficient values. From January 2009 higher correlation between $\sigma_{\text {ap }}$ and levoglucosan was observed, and for the last 40 days of sampling (25 January-7 March 2009) $R^{2}=0.84$. Although this was the time period during which the highest concentrations of levoglucosan were observed, one cannot exclude that the high correlation was a result of the Arctic haze phenomenon causing thorough mixing of aerosol particles from all sources entering the polar dome during this time of the year, rather than biomass burning (here: residential wood burning) being the major source of BC. No pronounced correlation was observed when correlating major inorganic aerosol constituents and $\mathrm{SO}_{2}$ with $\sigma_{\text {ap }}$, except for $\mathrm{SO}_{4}^{2-}\left(R^{2}=0.74\right)$. Consequently, we cannot point to either of the two suggested reasons explaining the high correlation observed between levoglucosan and $\sigma_{\text {ap }}$.

\subsection{Comparison of modeled and observed $\mathrm{EC}_{\mathrm{bb}}$}

The FLEXPART modeled $\mathrm{EC}_{\mathrm{bb}}$ (here: $\mathrm{EC}_{\mathrm{bb}, \mathrm{m}}$ ) from wildfires and agricultural fires (green curve) and residential wood burning (red curve) are shown in panel d in Fig. 2. The model captures the seasonal pattern of the levoglucosan time series with elevated levels in winter compared to summer. Also the mean seasonal concentration is in relatively good agreement, although the deviation during summer is considerably larger than during the winter period; i.e., the mean modeled winter and summer concentration of $\mathrm{EC}_{\mathrm{bb}, \mathrm{m}}$ was 8.5 and $4.0 \mathrm{ng} \mathrm{m}^{-3}$, respectively, compared to 3.9 (winter) and $0.9 \mathrm{ng} \mathrm{m}^{-3}$ (summer) obtained on the basis of the levoglucosan observations. Note that the observation-based means are slightly different from those presented in Sect. 4.3, as the population of samples compared consists of samples which have concurrent measurements of EBC as well.

We consider $\mathrm{OH}$ degradation of levoglucosan, levoglucosan emission ratios and uncertainties in the emissions to be the most important reasons for the observed deficit between the modeled and observational derived mean $\mathrm{EC}_{\mathrm{bb}}$. Uncertainties in emissions from biomass burning have been estimated to range from $-50 \%$ to $+200 \%$ for both contained (stoves, boilers) and open burning sources (Bond et al., 2004), and substantial differences between countries can appear. Also levoglucosan emission ratios are found to vary widely, as shown by e.g. Sullivan et al. (2008). The perhaps most important criterion for a tracer to be used in a quantitative manner is that its mass is conserved from emission source to receptor point or its degradation well known. Hence, in the current study, any selective depletion of levoglucosan following from reaction with the $\mathrm{OH}$ radical, as 
shown by e.g. Hoffmann et al. (2010), will cause an underestimation of $\mathrm{EC}_{\mathrm{bb}}$. Hence, the levoglucosan concentration observed at the Zeppelin observatory will provide minimum estimates of the biomass burning EC aerosol concentration. To explore the possible magnitude of $\mathrm{OH}$ degradation, we have recalculated the $\mathrm{EC}_{\mathrm{bb}, \mathrm{m}}$ model tracer with assumed chemical half-life times of $0.5,1,2,3,4$ and 5 days (see Table 3), spanning the range of half-life times of $12.7-83.2 \mathrm{~h}$ given by Hoffman et al. (2010), being shorter in summer compared to winter. The ratio between the modeled concentration of $\mathrm{EC}_{\mathrm{bb}, \mathrm{m}}$ assuming dry and wet deposition only and that of $\mathrm{EC}_{\mathrm{bb}, \mathrm{m}}$ including chemical degradation in addition to wet and dry deposition would then give the relative underestimation due to ignoring the chemical degradation. These ratios can in turn be used to provide chemical lifetime-corrected concentrations of $\mathrm{EC}_{\mathrm{bb}}$, denoted $\mathrm{EC}_{\mathrm{bb}}^{*}$ (see Table 3). When using chemical half-life times of levoglucosan ranging from 3 to 4 days for the wintertime period, including the $\tau_{1 / 2}$ values suggested for winter by Hoffmann et al. (2010), $\mathrm{EC}_{\mathrm{bb}}$ is underestimated by a factor of $5-7$, corresponding to an $\mathrm{EC}_{\mathrm{bb}}^{*}$ concentration ranging from 20 to $28 \mathrm{ng} \mathrm{m}^{-3}$. When using chemical half-life times of levoglucosan ranging from 0.5 to 2 days, which includes the $\tau_{1 / 2}$ values suggested for summer by Hoffmann et al. (2010), $\mathrm{EC}_{\mathrm{bb}}$ is underestimated by a factor of 130-4000. This in turn corresponds to an $\mathrm{EC}_{\mathrm{bb}}^{*}$ concentration range which far exceeds that of the summertime mean EBC concentration, and thus is unlikely.

A chemical lifetime of 4 days, which is in line with that suggested for winter (Hoffmann et al., 2010), provides an $\mathrm{EC}_{\mathrm{bb}}^{*}$ concentration of $18 \mathrm{ng} \mathrm{m}^{-3}$ for summer. This finding indicates that the chemical lifetime of levoglucosan during the Arctic summer is longer than that suggested by Hoffmann et al. (2010). It should be noted though, that a part, yet unknown, of the underestimation could be attributed to uncertainties in the emissions, as well as the levoglucosan emission ratio. Given the lower concentrations of $\mathrm{OH}$ in winter compared to summer, chemical lifetimes for levoglucosan extending beyond the range suggested by Hoffmann et al. (2010) could also be assumed during the Arctic winter. Indeed, the chemical lifetimes suggested by Hoffmann et al. (2010) are best estimates for typical tropospheric aqueous-phase oxidation processes under polluted continental plume conditions, and thus their use under other atmospheric conditions should be performed with caution. Nevertheless, Hoffmann et al. (2010) is the most comprehensive study published on this topic yet and thus is a natural choice for the current study.

Episodes of elevated concentrations of levoglucosan are in many cases nicely reflected in the modeled time series; however sometimes the timing and duration of the episodes are not captured well. During the spring and summer months, the model predicts two prolonged periods influenced by wildfires and agricultural fires at Zeppelin, both extending about one month in time, i.e., from 20 April to 20 May 2008 and from 1 August to 25 August 2008. The first of the two periods corre- sponds with an increase in the observed level of levoglucosan $\left(1.4 \mathrm{ng} \mathrm{m}^{-3}\right)$. However, the levoglucosan level does not continue with high values as long as predicted by the model. For the second part of the period the observed level of levoglucosan is below the summertime mean of $0.13 \mathrm{ng} \mathrm{m}^{-3}$. Unfortunately, during the August episode only a few levoglucosan measurements were available Observations of levoglucosan exist only for the first four days of August, for which the level increased to approximately $1 \mathrm{ng} \mathrm{m}^{-3}$ and hence corroborates to the increased levels from wildfires and agricultural fires predicted by the model.

The winter period is characterized by much higher background values and a number of peaks. The model predicts a period of increased emissions from residential wood burning from mid-November 2008 until the end of the sampling period in the beginning of March 2009. This is in line with the observation-based time series. For two of the most substantial periods, extending up to 13 (9-22 December 2008) and 18 days (13-31 January 2009) in length, the model matches well with the observed time series of levoglucosan, both with respect to onset and duration. The maximum of the first period was reached on 15 December, when the air was transported from central Europe. The maximum of the second period was observed on 17 January, when the source region was confined to the northern parts of central Europe, as well as for a region extending to the East and the West of the Ural mountain range, being centralized around the major Russian cities Perm and Sverdlovsk.

During the wintertime period there were two distinct episodes with a rapid increase in the levoglucosan and $\mathrm{EC}_{\mathrm{bb}}$ concentration, both indicated with an orange asterisk in Fig. 2 (panel c), that are not captured well by the model. One is the major episode observed during the transition of March to April (29 March to 6 April, 2008) with a maximum levoglucosan concentration of $5.6 \mathrm{ng} \mathrm{m}^{-3}$. The model predicts an influence by both agricultural fires/wildfires and residential wood burning during the period, but neither of the two sources, nor the sum of them, seems to reconstruct the evolution of the episode. The second episode is characterized by a sharp peak rising from 2 to 3 February 2009, reaching a peak levoglucosan concentration of $7.7 \mathrm{ng} \mathrm{m}^{-3}$. One plausible explanation of these observed deviations is the distribution and strength of the emissions used in the model. The days 29 March to 2 April during the 29 March to 6 April episode in 2008 is not captured well by the model, while the smaller peak on the 6 April is reproduced. From 27 March to 2 April, the air transport shifted from air masses originating mainly from the Arctic Ocean basin to increasingly include more of air masses from northern Russia. For the last part of the period, extending towards 6 April, the air masses were almost exclusively originating from the North-American continent, passing over the Arctic Ocean. This is illustrated in Fig. 4; panel a shows the emission flux of BC from the GFED and GAINS residential wood burning emissions for the month March 2008 [unit: $\mathrm{g} \mathrm{month}^{-1} \mathrm{~m}^{-2}$ ], whereas the footprint 
a) $B C$ emission $\left[\mathrm{g} / \mathrm{month} / \mathrm{m}^{2}\right]$

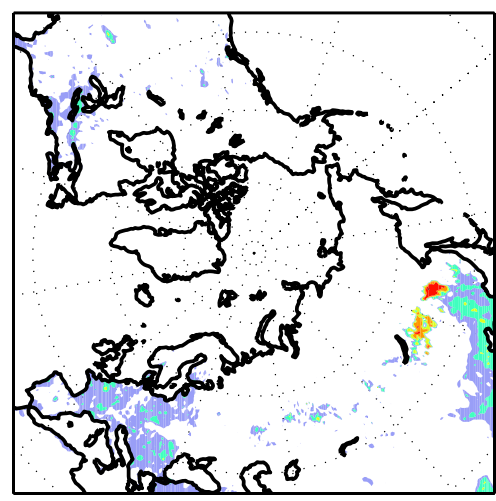

c) $2008-03-31$

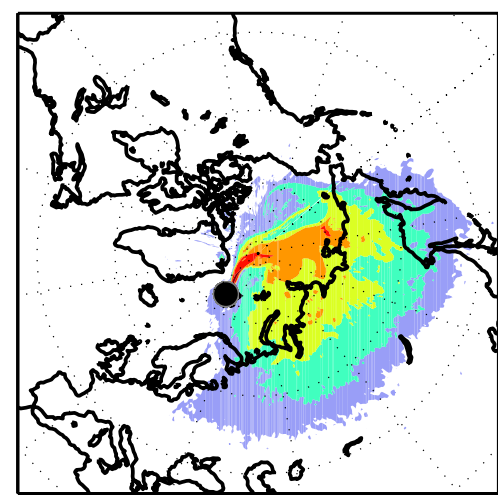

b) $2008-03-27$

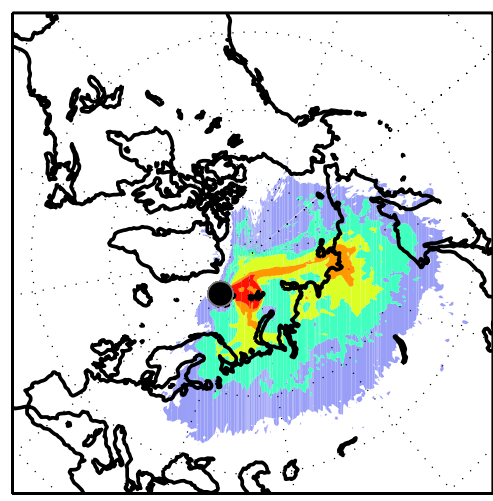

d) 2008-04-06

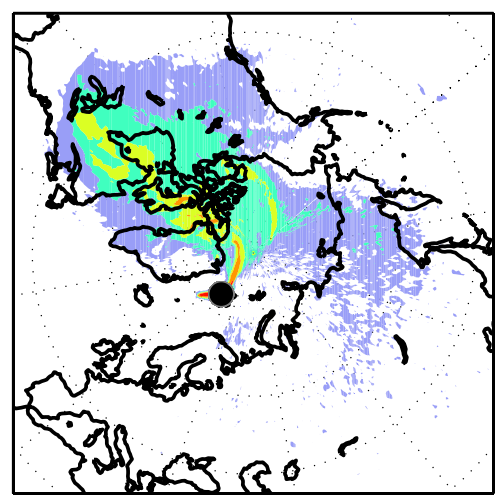

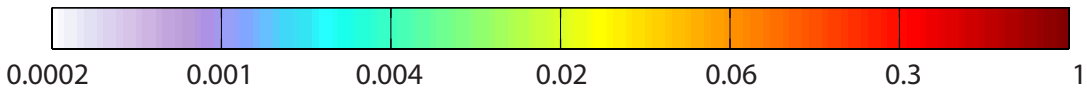

Figure 4. (a) shows the geographical distribution of the total emission flux of BC from GFED and GAINS biofuel emission for March 2008 $\left[\mathrm{kg} \mathrm{s}^{-1}\right]$. (b-d) shows the footprint sensitivities for the days 27 and 31 March and 6 April 2008.

sensitivities for the days 27 and 31 March and 6 April 2008 are shown in panel b-d.

A similar analysis was performed for the episode early in February, for which a rapid increase in the levoglucosan concentration was observed; i.e., it increased by a factor of 9 from 2 to 3 February. A corresponding increase was observed for EBC. Only a modest increase, starting earlier, is predicted by the model for these days, peaking at 4 to 5 February. For this episode there was a rapid shift in transport to the Zeppelin observatory from the Atlantic Ocean and northern Europe to air masses from the northern Russian region. These two examples indicate that there might be an underestimation in the emissions strength from residential wood burning in Russia, while such emissions from the other regions seem to fit relatively well with the observations. A more systemic study of the distribution of the emissions from residential wood burning in Russia is necessary to assess its importance for the $\mathrm{EC}_{\mathrm{bb}}$ level in the Arctic region.

\subsection{Relative contribution of $\mathrm{EC}_{\mathrm{bb}}$ to $\mathrm{EBC}$}

The monthly distribution of the relative contribution of $\mathrm{EC}_{\mathrm{bb}}$ to $\mathrm{EBC}$ is shown in Fig. 5. For the wintertime period $\mathrm{EC}_{\mathrm{bb}}$ was found to constitute $8.8 \pm 4.5 \%$ of $\mathrm{EBC}$ on average, whereas during summer $\mathrm{EC}_{\mathrm{bb}}$ constituted $6.1 \pm 3.4 \%$ of EBC on average. These are lower estimates as chemical degradation of levoglucosan has not been accounted for. The mean relative contribution of $\mathrm{EC}_{\mathrm{bb}}$ to $\mathrm{EBC}$ does not differ substantially between the summer and the wintertime periods, despite totally different regimes with elevated $\mathrm{EC}_{\mathrm{bb}}$ and EBC concentrations in winter compared to those in summer. As an example, the mean relative contribution of $\mathrm{EC}_{\mathrm{bb}}$ to EBC for September (14\%) was close to that observed for January (16\%), despite September recording the lowest monthly mean level of levoglucosan and EBC and January the highest ones. 


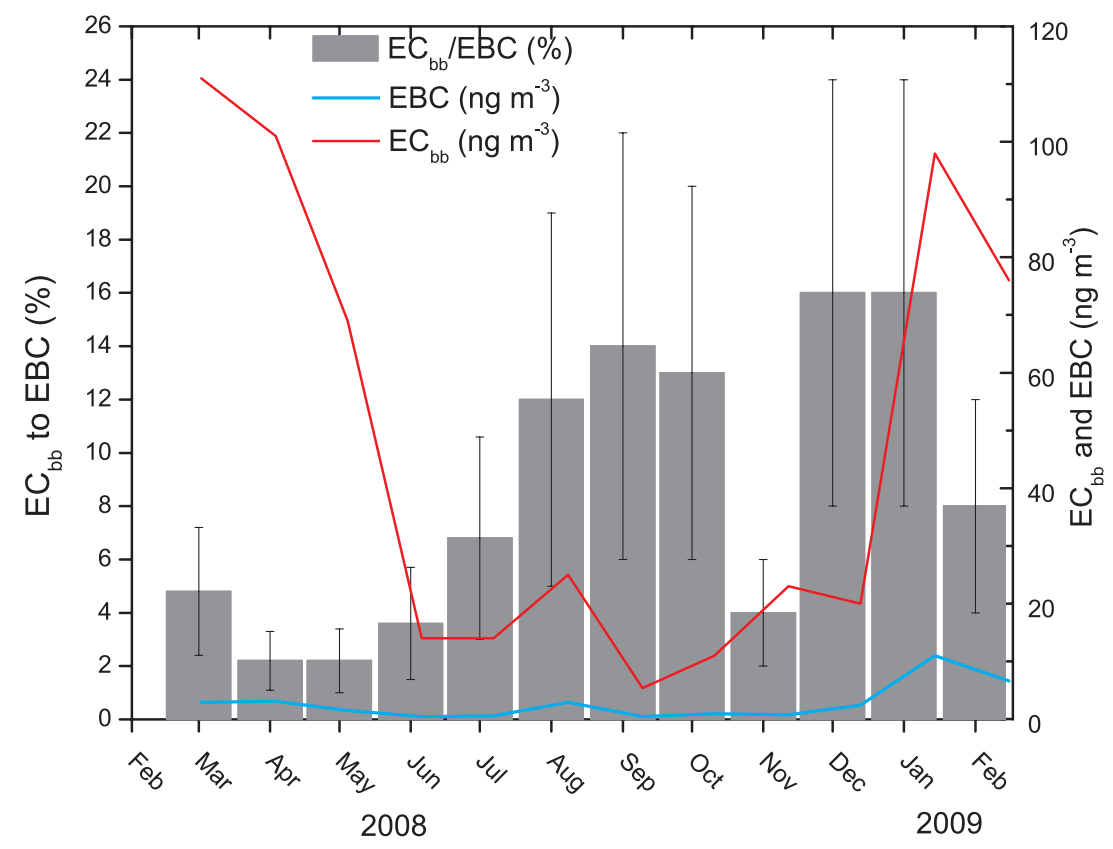

Figure 5. The grey bars show the monthly mean relative contribution of elemental carbon from biomass burning $\left(\mathrm{EC}_{\mathrm{bb}}\right)$ to total equivalent black carbon (EBC) at Zeppelin for the time period March 2008-February 2009 (left axis). Standard deviations are included. These values are lower estimates as degradation of levoglucosan are not accounted for. The light-blue curve is the monthly mean ambient concentration of elemental carbon from biomass burning $\left(\mathrm{EC}_{\mathrm{bb}}\right)$, whereas the red curve is that of equivalent black carbon (EBC) for the same period (right axis).

By means of the chemical-lifetime-corrected $\mathrm{EC}_{\mathrm{bb}}$ concentrations $\left(\mathrm{EC}_{\mathrm{bb}}^{*}\right)$ presented in Table 3, an upper estimate for the relative contribution of $\mathrm{EC}_{\mathrm{bb}}$ to $\mathrm{EBC}$ can be provided. During winter a chemical half-life time of levoglucosan ranging from 3 to 4 days corresponds to a mean relative contribution of $\mathrm{EC}_{\mathrm{bb}}^{*}$ to $\mathrm{EBC}$ of $31-45 \%$. For lifetimes ranging from 0.5 to 2 days the relative contribution of $\mathrm{EC}_{\mathrm{bb}}^{*}$ to EBC becomes unrealistically high for summer, i.e., in excess of $100 \%$. In summer, only a lifetime extending to 4 days or more provide a realistic mean contribution of $\mathrm{EC}_{\mathrm{bb}}^{*}$ to $\mathrm{EBC}$, i.e., $<65 \%$. Consequently, a reliable upper estimate of $\mathrm{EC}_{\mathrm{bb}}^{*}$ to $\mathrm{EBC}$ for summer cannot be provided based on the chemical lifetimes suggested for levoglucosan by Hoffmann et al. (2010).

A recent study suggests that $\mathrm{BC}$ emissions from gas flaring dominate the $\mathrm{BC}$ emissions in the Arctic at latitudes greater than $66^{\circ} \mathrm{N}$ and that flaring emissions contribute $42 \%$ to the annual mean BC surface concentrations in the Arctic (Stohl et al., 2013). The current study could support the conclusion by Stohl et al. (2013), at least in winter, as we find that $\mathrm{EC}_{\mathrm{bb}}^{*}$ account for 31-45\% of EBC at most; hence, fossil fuel sources of $\mathrm{BC}$ appear to be most important in the Arctic near the surface. No statement can be made on whether fossil fuel or biomass burning sources dominated during the warm season, as no reliable upper estimate of $\mathrm{EC}_{\mathrm{bb}}^{*}$ to $\mathrm{EBC}$ could be provided for summer based on the chemical lifetimes suggested by Hoffmann et al. (2010).

\section{Conclusions}

In the present study we have demonstrated the presence of biomass burning aerosol particles in the European Arctic based on measurements of levoglucosan at the Zeppelin observatory at Svalbard. To our knowledge this is the first time series of levoglucosan in the Arctic covering a full year.

Elevated concentrations of levoglucosan in winter ( $\left.1.02 \mathrm{ng} \mathrm{m}^{-3}\right)$ compared to summer $\left(0.13 \mathrm{ng} \mathrm{m}^{-3}\right)$ were observed, resembling the seasonal variation seen for e.g. sulfate and $\mathrm{BC}$ caused by the Arctic haze phenomenon. The wintertime mean concentration of levoglucosan was 2-3 orders of magnitude less than that reported for European urban areas and 1-2 orders of magnitude less than that of the European rural background environment.

Neglecting chemical degradation by $\mathrm{OH}$ provides minimum levoglucosan concentrations, corresponding to a mean $\mathrm{EC}_{\mathrm{bb}}$ concentration of $3.7 \pm 1.2 \mathrm{ng} \mathrm{m}^{-3}$ in winter (OctoberApril) and $0.8 \pm 0.3 \mathrm{ng} \mathrm{m}^{-3}$ in summer (May-September), or $8.8 \pm 4.5 \%$ of the measured equivalent black carbon (EBC) concentration in winter and $6.1 \pm 3.4 \%$ in summer. When accounting for $\mathrm{OH}$ degradation of levoglucosan, 31-45\% of $\mathrm{EBC}$ could be attributed to $\mathrm{EC}_{\mathrm{bb}}^{*}\left(\mathrm{EC}_{\mathrm{bb}}\right.$ adjusted for chemical degradation) in winter, whereas no reliable upper estimate could be provided for summer based on the chemical lifetimes suggested for levoglucosan by Hoffmann et al. (2010). Hence, fossil fuel sources appear to dominate the European 
Arctic BC concentrations in winter, whereas we cannot conclude upon this for the warm season. We recommend that complementary, observation-based approaches, such as e.g. radiocarbon measurements of $\mathrm{EC}$, should be undertaken in the near future to narrow the range reported for $\mathrm{EC}_{\mathrm{bb}}$ to $\mathrm{EBC}$ in the current study. Note, however, that the annual Arctic EBC loading is dominated by the wintertime sources; thus focus should be to understand these in more detail for a successful mitigation. On the other hand, winter values are not as important as summer values from a radiative forcing (climate) perspective, although they do lead to $\mathrm{BC}$ deposition on snow and ice, which leads to a reduction of the snow/ice albedo, which may persist into spring/summer.

Results from the current study indicate that the chemical lifetime of levoglucosan in the Arctic atmosphere is longer than that suggested by Hoffmann et al. (2010) for polluted continental plume conditions.

Calculations using the Lagrangian particle dispersion model FLEXPART show that the seasonal variation of the modeled $\mathrm{EC}_{\mathrm{bb}}$ concentration compared relatively well with observationally derived $\mathrm{EC}_{\mathrm{bb}}$ from agricultural fires/wildfires during summer, and residential wood burning in winter. The model overestimates by a factor of 2.2 in winter and 4.4 in summer when compared to the observationally derived mean $\mathrm{EC}_{\mathrm{bb}}$ concentration, which provides the minimum estimate, whereas it underestimates by a factor of 2.33.3 in winter and a factor of 4.5 in summer when compared to $\mathrm{EC}_{\mathrm{bb}}^{*}$, which provides the upper estimate.

The current study indicates that emissions of residential wood burning in northern Russia, a region of great importance for the $\mathrm{BC}$ concentrations observed in the European Arctic, might be too low. This topic needs further investigation.

Acknowledgements. The research leading to these results has received funding from the Norwegian Research Council through the POLARCAT project, as well as from the European Union Seventh Framework Programme (FP7/2007-2013) under grant agreement no. 282688 - ECLIPSE. We thank ECMWF and met.no for granting access to ECMWF analysis data. We would also like to acknowledge the access to fire emissions from the Global Fire Emissions Database version 3 (GFED3). Finally, Dr. Sanna Saarikoski at the Finnish Meteorological Institute is acknowledged for providing access to the raw data presented in Saarikoski et al. (2007).

Edited by: P. DeCarlo

\section{References}

Amann, M., Bertok, I., Borken-Kleefeld, J., Cofala, J., Heyes, C., Höglund-Isaksson, L., Klimont, Z., Nguyen, B., Posch, M., Rafaj, P., Sander, R., Schöpp, W., Wagner, F., and Winiwarter, W.: Cost-effective control of air quality and greenhouse gases in Europe: modeling and policy applications, Environ. Mod. Software, 26, 1489-1501, doi:10.1016/j.envsoft.2011.07.012, 2011.

Birch, M. E. and Cary. R. A.: Elemental carbon-based method for monitoring occupational exposures to particulate diesel exhaust, Aerosol Sci. Technol., 25, 221-241, 1996.

Bond, T. C.: Can warming particles enter global climate discussions? Environ. Res. Lett., 2, 045030, doi:10.1088/1748 9326/2/4/045030, 2007.

Bond, T. C., Anderson, T. L., and Campbell, D.: Calibration and intercomparison of filter-based measurements of visible light absorption by aerosols, Aerosol Sci. Technol., 30, 582-600, 1999.

Bond, T. C., Streets, D. G., Yarber, K. F., Nelson, S. M., Woo, J.-H., and Klimont, Z.: A technology-based global inventory of black and organic carbon emissions from combustion, J. Geophys. Res., 109, D14203, doi:10.1029/2003JD003697, 2004.

Brock, C. A., Cozic, J., Bahreini, R., Froyd, K. D., Middlebrook, A. M., McComiskey, A., Brioude, J., Cooper, O. R., Stohl, A., Aikin, K. C., de Gouw, J. A., Fahey, D. W., Ferrare, R. A., Gao, R.-S., Gore, W., Holloway, J. S., Hübler, G., Jefferson, A., Lack, D. A., Lance, S., Moore, R. H., Murphy, D. M., Nenes, A., Novelli, P. C., Nowak, J. B., Ogren, J. A., Peischl, J., Pierce, R. B., Pilewskie, P., Quinn, P. K., Ryerson, T. B., Schmidt, K. S., Schwarz, J. P., Sodemann, H., Spackman, J. R., Stark, H., Thomson, D. S., Thornberry, T., Veres, P., Watts, L. A., Warneke, C., and Wollny, A. G.: Characteristics, sources, and transport of aerosols measured in spring 2008 during the aerosol, radiation, and cloud processes affecting Arctic Climate (ARCPAC) Project, Atmos. Chem. Phys., 11, 2423-2453, doi:10.5194/acp-11-24232011, 2011.

Cavalli, F., Viana, M., Yttri, K. E., Genberg, J., and Putaud, J.-P.: Towards a standardized thermal-optical protocol for measuring atmospheric organic and elemental carbon: The EUSAAR protocol, Atmos. Meas. Tech., 2, 79-89, doi:10.5194/amt-2-79-2010, 2010.

Clarke, A. D. and Noone, K. J.: Soot in the arctic snowpack - A cause for perturbations in radiative-transfer. Atmospheric Environment 19, 2045-2053, 1985.

Dye, C. and Yttri, K. E.: Determination of monosaccharide anhydrides in atmospheric aerosols by use of high-resolution mass spectrometry combined with high performance liquid chromatography, Anal. Chem., 77, 1853-1858, 2005.

Eleftheriadis, K., Vratolis, S., and Nyeki, S.: Aerosol black carbon in the European Arctic: Measurements at Zeppelin Station, Ny-Ålesund, Svalbard from 1998-2007, Geophys. Res. Lett., 36, L02809, doi:10.1029/2008GL035741, 2009.

Energy Information Administration (EIA): International energy outlook 2008, EIA, Washington, DC, USA, 2008.

Fine, P. M., Cass, G. R., and Simoneit, B. R. T.: Chemical characterization of fine particle emissions from the fireplace combustion of woods grown in the Northeastern United States, Environ. Sci Technol., 35, 2665-2675, 2001.

Fine, P. M, Cass, G. R., and Simoneit, B. R. T.: Chemical characterization of fine particle emissions from the fireplace combustion of 
woods grown in the Southern United States, Environ. Sci. Technol., 36, 1442-1451, 2002a.

Fine, P. M., Cass, G. R., and Simoneit, B. R. T.: Organic compounds in biomass smoke from residential wood combustion: Emissions characterization at a continental scale, J. Geophys. Res., 107, D8349, doi:10.1029/2001JD000661, 2002b.

Fine, P. M., Cass, G. R., and Simoneit, B. R. T.: Chemical characterization of fine particle emissions from the fireplace combustion of wood types grown in the Midwestern and Western United States, Environ. Eng. Sci., 21, 387-409, 2004.

Fraser, M. P. and Lakshmanan, K.: Using levoglucosan as a molecular marker for the long range transport of biomass combustion aerosols, Environ. Sci. Technol., 34, 4560-4564, 2000.

Fu, P. Q., Kawamura, K., and Barrie, L. A.: Photochemical and other sources of organic compounds in the Canadian high Arctic aerosol pollution during winter-spring, Environ. Sci. Technol., 43, 286-292, 2009.

Fu, P. Q., Kawamura, K., Chen, J., Charrière, B., and Sempéré, R.: Organic molecular composition of marine aerosols over the Arctic Ocean in summer: contributions of primary emission and secondary aerosol formation, Biogeosciences, 10, 653-667, doi:10.5194/bg-10-653-2013, 2013.

Gao, S., Hegg, D. A., Hobbs, P. V., Kirchstetter, T. W., Magi, B. I., and Sadilek, M.: Watersoluble organic components in aerosols associated with savanna fires in southern Africa: Identification, evolution, and distribution, J. Geophys. Res. 108, D8491, doi:10.1029/2002JD002324, 2003.

Gelencsér, A., May, B., Simpson, D., Sánchez-Ochoa, A., KasperGiebl, A., Puxbaum, H., Caseiro, A., Pio, C., and Legrand, M.: Source apportionment of $\mathrm{PM}_{2.5}$ organic aerosol over Europe: primary/secondary, natural/anthropogenic, fossil/biogenic origin, J. Geophys. Res., 112, D23S04, doi:10.1029/2006JD008094, 2007.

Genberg, J., Denier van der Gon, H. A. C, Simpson, D. Swietlicki, E., Areskoug, H., Beddows, D., Ceburnis, D., Fiebig, M., Hansson, H. C., Harrison, R. M., Jennings, S. G., Saarikoski, S., Spindler, G., Visschedijk, A. J. H., Wiedensohler, A., Yttri, K. E., and Bergström, R.: Light-absorbing carbon in Europe - measurement and modelling, with a focus on residential wood combustion emissions, Atmos. Chem. Phys., 13, 87198738, doi:10.5194/acp-13-8719-2013, 2013.

Hand, J. L., Schichtel, B. A., Malm, W. C., and Pitchford, M. L.: Particulate sulfate ion concentration and $\mathrm{SO}_{2}$ emission trends in the United States from the early 1990s through 2010, Atmos. Chem. Phys., 12, 10353-10365, doi:10.5194/acp-1210353-2012, 2012.

Hansen, J., Sato, M., Ruedy, R., Lacis, A., and Oinas, V.: Global warming in the twenty-first century: An alternative scenario, $\mathrm{P}$. Natl. Acad. Sci. USA, 97, 9875-9880, 2000.

Hansen, J. and Nazarenko, L.: Soot climate forcing via snow and ice albedos, P. Natl. Acad. Sci., 101, 423-428, doi:10.1073/pnas.2237157100, 2004.

Hedberg, E., Johansson, C., Johansson, L., Swietlicki, E., and Brorström-Lundén, E.: Is levoglucosan a suitable quantitative tracer for wood burning? Comparison with receptor modeling on trace elements in Lycksele, Sweden, J. Air Waste Manage. Assoc., 56, 1669-1678, 2006.

Hegg, D.A., Warren, S. G., Grenfell, T. C., Doherty, S. J., Larson, T. V., and Clarke, A. D.: Source attribution of black car- bon in Arctic snow, Environ. Sci. Technol., 43, 4016-4021, doi:10.1021/es803623f, 2009.

Hegg, D. A., Clarke, A. D., Doherty, S. J., and Ström, J.: Measurements of black carbon aerosol washout ratio on Svalbard. Tellus B, 63, 891-900, doi:10.1111/j.1600-0889.2011.00577, 2011.

Hennigan, C. J., Sullivan, A. P., Collett Jr., J. L., and Robinson, A. L.: Levoglucosan stability in biomass burning particles exposed to hydroxyl radicals, Geophys. Res. Lett., 37, L09806, doi:10.1029/2010GL043088, 2010.

Hirdman, D., Burkhart, J. F., Sodemann, H., Eckhardt, S., Jefferson, A., Quinn, P. K., Sharma, S., Ström, J., and Stohl, A.: Longterm trends of black carbon and sulphate aerosol in the Arctic: changes in atmospheric transport and source region emissions, Atmos. Chem. Phys., 10, 9351-9368, doi:10.5194/acp-10-93512010, 2010a.

Hirdman, D., Sodemann, H., Eckhardt, S., Burkhart, J. F., Jefferson, A., Mefford, T., Quinn, P.K., Sharma, S., Ström, J., and Stohl, A.: Source identification of short-lived air pollutants in the Arctic using statistical analysis of measurement data and particle dispersion model output, Atmos. Chem. Phys., 10, 669-693, doi:10.5194/acp-10-669-2010, 2010.

Hoffmann, D., Tilgner, A., Iinuma, Y., and Herrmann, H.: Atmospheric stability of levoglucosan: a detailed laboratory and modeling study, Environ. Sci. Technol., 44, 694-699, doi:10.1021/es902476f, 2010.

Jacobson, M. Z.: Control of fossil-fuel particulate black carbon and organic matter, possibly the most effective method of slowing global warming, J. Geophys. Res. 107, 4410, doi:10.1029/2001JD001376, 2002.

Kleeman, M. J., Schauer, J. J., and Cass, G.: Size and composition distribution of fine particulate matter emitted from wood burning, meat charbroiling, and cigarettes, Environ. Sci. Technol., 33, 3516-3523, 1999.

Klimont, Z., Kupiainen, K., Heyes, Ch., Purohit, P., Cofala, J., Rafaj, P., and Schoepp, W.: Global anthropogenic emissions of particulate matter, in preparation, 2014.

Kupiainen, K. and Klimont, Z.: Primary emissions of fine carbonaceous particles in Europe, Atmos. Environ., 41, 2156-2170, doi:10.1016/j.atmosenv.2006.10.066, 2007.

Lanz, V. A., Prévôt, A. S. H., Alfarra, M. R., Weimer, S., Mohr, C., DeCarlo, P. F., Gianini, M. F. D., Hueglin, C., Schneider, J., Favez, O., D’Anna, B., George, C., and Baltensperger, U.: Characterization of aerosol chemical composition with aerosol mass spectrometry in Central Europe: an overview, Atmos. Chem. Phys., 10, 10453-10471, doi:10.5194/acp-10-10453-2010, 2010.

Locker, H. B.: The use of Levoglucosan to assess the environmental impact of residential wood burning on air quality. Ph.D. Thesis, Dartmouth College, Hanover, NH, 1988.

MacCracken, M. C., Cess, R. D., and Potter, G. L.: Climatic effects of anthropogenic arctic aerosols: An illustration of climate feedback mechanisms with one- and two-dimensional climate models, J. Geophys. Res., 91, 14445-14450, 1986.

Maenhaut, W., Vermeylen, R., Claeys, M., Vercauteren, J., Matheeussen, C., and Roekens, E. Assessment of the contribution from wood burning to the $\mathrm{PM}_{10}$ aerosol in Flanders, Belgium. Science of the Total Environment, 437, 226-236, 2012.

Mazzoleni, L., Zielinska, B., and Moosmuller, H.: Emissions of levoglucosan, methoxy phenols, and organic acids from prescribed 
burns, laboratory combustion of wildland fuels, and residential wood combustion, Environ. Sci. Technol., 41, 2115-2122, 2007.

Murphy, D. M., Chow, J. C., Leibensperger, E. M., Malm, W. C., Pitchford, M., Schichtel, B. A., Watson, J. G., and White, W. H.: Decreases in elemental carbon and fine particle mass in the United States, Atmos. Chem. Phys., 11, 4679-4686, doi:10.5194/acp-11-4679-2011, 2011

Myhre, G., Myhre, C. E. L., Samset, B. H., and Storelvmo, T.: Aerosols and their relation to global climate and climate sensitivity, Nature Education Knowledge, 4, 5, 7, available at: http://www.nature.com/scitable/knowledge/library/ aerosols-and-their-relation-to-global-climate-102215345, 2013.

Oja, V. and Suuberg, E. M.: Vapor Pressures and Enthalpies of Sublimation of D-glucose, D-xylose, Cellobiose, and Levoglucosan, J. Chem. Eng. Data, 33, 26-29, 1999.

Petzold, A., Ogren, J. A., Fiebig, M., Laj, P., Li, S.-M., Baltensperger, U., Holzer-Popp, T., Kinne, S., Pappalardo, G., Sugimoto, N., Wehrli, C., Wiedensohler, A., and Zhang, X.-Y.: Recommendations for reporting "black carbon" measurements, Atmos. Chem. Phys., 13, 8365-8379, doi:10.5194/acp-13-83652013, 2013.

Pueschel, R. F. and Kinne, S. A.: Physical and radiative properties of Arctic atmospheric aerosols, Sci. Total Environ., 160-161, 811824, doi:10.1016/0048-9697(95)04414-V, 1995.

Puxbaum, H. Caseiro, A., Sánchez-Ochoa, Kasper-Giebl, A., Claeys, M., Gelencsér, A., Legrand, M., Preunkert, S., and Pio, C. A.: Levoglucosan levels at background sites in Europe for assessing the impact of biomass combustion on the European, aerosol background, J. Geophys. Res., 112, D23S05, doi:10.1029/2006JD008114, 2007.

Quinn, P., Shaw, G., Andrews, E., Dutton, E., Ruoho-Airola, T., and Gong, S.: Arctic haze: Current trends and knowledge gaps, Tellus B, 59, 99-114, 2007.

Saarikoski, S., Sillanpaa, M., Sofiev, M., Timonen, H., Saarnio, K., Teinela, K., Karppinen, A., Kukkonen, J., and Hillamo, R.: Chemical composition of aerosols during a major biomass burning episode over northern Europe in spring 2006: Experimental and modelling assessments, Atmos. Environ., 41, 3577-3589, 2007.

Schmidl, C., Marr, I. L., Caseiro, A., Kotianova, P., Berner, A., Bauer, H., Kasper-Giebl, A. and Puxbaum, H.: Chemical characterisation of fine particle emissions from wood stove combustion of common woods growing in mid-European Alpine regions, Atmos. Environ., 42, 126-141, 2008

Sillanpää, M., Hillamo, R., Saarikoski, S., Frey, A., Pennanen, A., Makkonen, U., Spolnik, Z., Van Grieken, R., Branis, M., Brunekreef, B., Chalbot, M. C., Kuhlbusch, T., Sunyer, J., Kerminen, V. M., Kulmala, M., and Salonen, R. O.: Chemical composition and mass closure of particulate matter at six urban sites in Europe, Atmos. Environ., 40, S212-S223, 2006.

Simoneit, B. R. T., Schauer, J. J., Nolte, C. G., Oros, D. R., Elias, V. O., Fraser, M. P., Rogge, W. F., and Cass., G. R.: Levoglucosan, a tracer for cellulose in biomass burning and atmospheric particles, Atmos. Environ., 33, 173-182, 1999.

Sharma, S., Ishizawa, M., Chan, D., Lavoué, D., Andrews, E., Eleftheriadis, K., and Maksyutov, S.: 16-year simulation of Arctic black carbon: Transport, source contribution, and sensitivity analysis on deposition, J. Geophys. Res. Atmos., 118, 943-964, doi:10.1029/2012JD017774, 2013.
Shaw, G. E.: The Arctic Haze phenomenon, B. Am. Meteor. Soc., 76, 2403-2413, 1995.

Shindell, D., Kuylenstierna, J. C. I., Vignati, E., Van Dingenen, R., Amann, M., Klimont, Z., Anenberg, S. C., Muller, N., JanssensMaenhout, G., Raes, F., Schwartz, J., Faluvegi, G., Pozzoli, L., Kupiainen, K., Höglund-Isaksson, L., Emberson, L., Streets, D. Ramanathan, V., Hicks, K., Oanh, N. T. K., Milly, G., Williams, M., Demkine, V., and Fowler, D.: Simultaneously mitigating near-term climate change and improving human health and food security, Science, 335, 183-189, 2012.

Stohl, A. and Thomson, D. J.: A density correction for Lagrangian particle dispersion models, Bound.-Lay. Meteorol., 90, 155-167, 1999.

Stohl, A., Hittenberger, M., and Wotawa, G.: Validation of the Lagrangian particle dispersion model FLEXPART against large scale tracer experiment data, Atmos. Environ., 32, 4245-4264, 1998.

Stohl, A., Forster, C., Frank, A., Seibert, P., and Wotawa, G.: Technical note: The Lagrangian particle dispersion model FLEXPART version 6.2, Atmos. Chem. Phys., 5, 2461-2474, doi:10.5194/acp-5-2461-2005, 2005.

Stohl, A., Andrews, E., Burkhart, J. F., Forster, C., Herber, A., Hoch, S. W., Kowal, D., Lunder, C., Mefford, T., Ogren, J. A., Sharma, S., Spichtinger, N., Stebel, K., Stone, R., Ström, J., Tørseth, K., Wehrli, C., and Yttri, K. E.: Pan-Arctic enhancements of light absorbing aerosol concentrations due to North American boreal forest fires during summer 2004. J. Geophys. Res., 111, D22214, doi:10.1029/2006JD007216, 2006.

Stohl, A., Berg, T., Burkhart, J. F., Fjæraa, A. M., Forster, C., Herber, A., Hov, Ø., Lunder, C., McMillan, W. W., Oltmans, S., Shiobara, M., Simpson, D., Solberg, S., Stebel, K., Ström, J., Tørseth, K., Treffeisen, R., Virkkunen, K., and Yttri, K. E.: Arctic smoke - record high air pollution levels in the European Arctic due to agricultural fires in Eastern Europe, Atmos. Chem. Phys., 7, 511 534, doi:10.5194/acp-7-511-2007, 2007.

Stohl, A., Klimont, Z., Eckhardt, S., Kupiainen, K., Shevchenko, V. P., Kopeikin, V. M., and Novigatsky, A. N.: Black carbon in the Arctic: the underestimated role of gas flaring and residential combustion emissions, Atmos. Chem. Phys., 13, 8833-8855, doi:10.5194/acp-13-8833-2013, 2013.

Sullivan, A. P., Holden, A. S., Patterson, L. A., McMeeking, G. R., Kreidenweis, S. M., Malm, W. C., Hao, W. M., Wold, C. E., and Collett Jr., J. L.: A method for smoke marker measurements and its potential application for determining the contribution of biomass burning from wildfires and prescribed fires to ambient $\mathrm{PM}_{2.5}$ organic carbon,J. Geophys. Res., 113, D22302, doi:10.1029/2008JD010216, 2008.

Szidat, S., Ruff, M., Perron, N., Wacker, L., Synal, H.-A., Hallquist, M., Shannigrahi, A. S., Yttri, K. E., Dye, C., and Simpson, D. Fossil and non-fossil sources of organic carbon (OC) and elemental carbon (EC) in Göteborg, Sweden. Atmos. Chem. Phys., 9, 1521-1535, doi:10.5194/acp-9-1521-2009, 2009.

Torseth, K., Aas, W., Breivik, K., Fjæraa, A. M., Fiebig, M., Hjellbrekke, A. G., Lund Myhre, C., Solberg, S., and Yttri, K. E.: Introduction to the European Monitoring and Evaluation Programme (EMEP) and observed atmospheric composition change during 1972-2009, Atmos. Chem. Phys., 12, 5447-5481, doi:10.5194/acp-12-5447-2012, 2012. 
van der Werf, G. R., Randerson, J. T., Giglio, L., Collatz, G. J., Mu, M., Kasibhatla, P. S., Morton, D. C., DeFries, R. S., Jin, Y., and van Leeuwen, T. T.: Global fire emissions and the contribution of deforestation, savanna, forest, agricultural, and peat fires (19972009), Atmos. Chem. Phys., 10, 11707-11735, doi:10.5194/acp10-11707-2010, 2010.

von Schneidemesser, E., Schauer, J. J., Hagler, G. S. W., and Bergin, M. H.: Concentrations and sources of carbonaceous aerosol in the atmosphere of Summit, Greenland, Atmos. Environ., 43, 41554162, 2009.

Warneke, C., Bahreini, R., Brioude, J., Brock, C. A., de Gouw, J. A., Fahey, D. W., Froyd K. D., Holloway, J. S., Middlebrook, A., Miller, L., Montzka, S., Murphy, D. M., Peischl, J., Ryerson, T. B., Schwarz, J. P., Spackman, J. R., and Veres, P.: Biomass burning in Siberia and Kazakhstan as an important source for haze over Alaskan Arctic in April 2008, Geophys. Res. Lett., 36, L02813, doi:10.1029/2008GL036194, 2009.

Yttri, K. E., Dye, C., Slørdal, L. H., and Braathen, O.-A.: Quantification of monosaccharide anhydrides by negative electrospray HPLC/HRMS-TOF - Application to aerosol samples from an urban and a suburban site influenced by small scale wood burning, J. Air Waste Manage. Assoc., 55, 1169-1177, 2005.

Yttri, K. E., Dye, C., Braathen, O.-A., Simpson, D., and Steinnes, E.: Carbonaceous aerosols in Norwegian urban sites. Atmos. Chem. Phys., 9, 2007-2020, doi:10.5194/acp-9-2007-2009, 2009.
Yttri, K. E., Simpson, D., Stenström, K., Puxbaum, H., and Svendby, T.: Source apportionment of the carbonaceous aerosol in Norway - quantitative estimates based on ${ }^{14} \mathrm{C}$, thermal-optical and organic tracer analysis, Atmos. Chem. Phys., 11, 9375-9394, doi:10.5194/acp-11-9375-2011, 2011a.

Yttri, K. E., Simpson, D., Nøjgaard, J. K., Kristensen, K., Genberg, J., Stenström, K., Swietlicki, E., Hillamo, R., Aurela, M., Bauer, H., Offenberg, J. H., Jaoui, M., Dye, C., Eckhardt, S., Burkhart, J. F., Stohl, A., and Glasius, M.: Source apportionment of the summertime carbonaceous aerosol at Nordic rural background sites, Atmos. Chem. Phys., 11, 13339-13357. doi:10.5194/acp11-13339-2011, 2011b.

Yttri, K. E.: Source apportionment of the carbonaceous aerosol in the European regional background environment - Impact of anthropogenic sources, in preparation, 2014.

Zangrando, R., Barbaro, E., Zennaro, P., Rossi, S., Kehrwald, N. M., Gabrieli, J., Barbante, C., and Gambaro, A.: Molecular markers of biomass burning in Arctic aerosols, Environ. Sci. Technol., 47, 8565-8574, doi:10.1021/es400125r, 2013.

Zdráhal, Z., Oliveira, J., Vermeylen, R., Claeys, M., and Maenhaut, W.: Improved method for Quantifying Levoglucosan and Related Monosaccharide Anhydrides in Atmospheric Aerosols and Application to Samples from Urban and Tropical Locations, Environ. Sci. Technol., 36, 747-757, 2002. 